\title{
Navigating Quality Madrasah: MAN IC, Principle Performance, Teacher Performance, Positive Psychological Capital and Student Achievement
}

\author{
Achmad Syahid \\ Lecturer of Faculty of Psychology of UIN Syarif Hidayatullah Jakarta \\ achmad_syahid@uinjkt.ac.id
}

\begin{abstract}
This article identifies how the quality of the MAN IC institution, the leadership of the principle of madrasah directs the institutional madrasa as an educational unit, teacher performance to navigate of the teaching and learning process, which includes teacherstudent achievement and positive psychological capital student influence on the achievement of MAN IC students' achievements. The measure of the student achievement can be seen from the UN scores and their acceptance at domestic and foreign universities with high competition. This research took place at $25 \mathrm{MAN}$ IC, taking into account that MAN IC is a leading madrasa so that it has high achievements in the UN in majoring of natural sciences, social sciences and their acceptance at well-known domestic and foreign universities. It was a qualitative study with a case study approach. Data collected through and documentary study. The research results show that MAN IC students have very high achievements in the UN and the average students are accepted at the best domestic and foreign universities consistently and sustainably.
\end{abstract}

Keywords: MAN IC, Madrasah Principle, Teacher Performance, Teacher-Student Engagement, Student Achievement.

\section{Introduction}

Reading the educational history of the alumni of the MAN Jember Special Program (MANPK) in Santri Kaliwates (Maftuhin, 2020), perhaps what appears from their learning traditions is the "in love of knowledge" as described by Pranoto (2019). Different character of school quality under the Ministry of National Education (MoNE) environment, as recorded in research byPusporini, Triana, Syahid and Kustandi (2020). Historically, the MAN PK was formed by Munawir Syadzali, Minister of Religious Affairs for the Period of 1983-1993, who was named by Effendy, Prasetyo and Subhan (in Azra and Umam, 1998)as the era of "Disbursement of Ideological Tension". This MAN PK is a program within Islamic educational institutions that are managed as in the pesantren tradition but within the madrasa. This is a new synthesis from Steenbrink (1986) which separates pesantren, schools and madrassas in the modern era.

Looking back, since the second half of the 20th century, madrassas experienced modernization and reform along with the country's mission and mandate towards them(Syahid, 2018). Madrasas then appointed as one type of Islamic religious education institution which is one of the sub-systems of national education(Rahim, 2001). In addition to Islamic religious education is known as Christian religious education, Catholic, Hindu, Buddha and Confucious. Madrasa is one of the formal Islamic educational institutions since the level of primary to secondary education spread throughout Indonesia. According to data EMIS 2018/2019 that the number of Madrasah Aliyah (MA) is 8,807 of the total madrasas are 52,522 institutions, the rest 
are Madrasah Ibtidaiyah (MI) and Madrasah Tsanawiyah (M.Ts.). From that percentage, the total private madrasas are around $93 \%$ while the remaining $7 \%$ are public madrasas. The total number of students who can be accommodated by madrasas at the MI level is 3,797,438 students, M. Ts. around 2,883,546 students while at the MA level around 1,323,656 students. Study of the national education system is called De Witte, Titl, Holz and Smet (2019) as an effort to recognize its anatomy in order to provide inclusive education services.

The large percentage of private madrasas compared to public madrassas in Indonesia shows the high preference of Muslim parents towards madrasa administrators. The more open access of Muslim children to obtain affordable education services, despite the problems in the aspects of quality, relevance and competitiveness. BAN S/M data in 2018 show that only 7,100 M.I., 3,131 MTs., and 1,730 MAs were accredited. Nationally, the number of MI to MA accredited is more than $50 \%$ in only 4 provinces, in the remaining provinces it is not up to $40 \%$. The number of accredited MIs is spread across three provinces, respectively, East Java, Central Java and West Java. While the number of MIs that won accreditation A was only spread in North Sumatra and South Sulawesi. Accredited MTs are only concentrated in three provinces: West Java, Central Java and East Java. From the data, the provinces with the number of MTs which in 2018 had achieved accreditation A of more than $50 \%$ were only spread in 4 provinces: DI Yogyakarta and DKI Jakarta, followed by West Paupa and East Nusa Tenggara. However, the provinces with the highest number of A-accredited MTs are actually scattered in other provinces, namely Banten and East Java, then South Sumatra. While the provinces with the number of accredited MA are spread in West Java, East Java and Central Java. Whereas provinces with more than $50 \%$ of MAs with A accreditation are DI Yogyakarta, DKI Jakarta, then West Papua and East Nusa Tenggara. Statistical data on the distribution of madrasah accreditation from BAN S/M at the MI to MA levels above confirms the facts about madrasah institutional quality disparities that are still wide open. Up to the 1990s quality was still a crucial issue of madrasas, even though madrasas had opened good access to education services, bridging the relevance of education and the competitiveness of the nation's children.

At the moment most of the madrasa population is of low quality, complicating and hampering the positive role of Muslims in the nation. It will be a burden on the state, not a determinant of success. After receiving an SMU IC overflow from BPPT, the Ministry of Religious Affairs (MoRA) changed it to MAN IC. He is referred to as 'advanced madrasa in term of quality", the Ministry of Religion places MAN IC academically as "superior madrasa", in addition to madrasa skills programs and religious program madrassas (PMA 60/2015), similar to MAN PK as a superior program. Along with the increasingly complex complexity of the nation's strategic problems, if previously MAN PK was given the mandate to print intellectual scholars, then MAN IC was believed to be the type of madrasa capable of producing a balanced nation's cadres in mastery in the field of faith and piety with science and technology. Institutionally MAN IC is also expected to be a model for public or private MA in Indonesia in terms of producing quality students (Sukarno, 2013). The embryo of MAN IC was pioneered from SMU IC which since 1996/1997 as part of the World Bank's STEP (Science and Technology Equity Program) for formal school alumni in the boarding school environmentwas given to the MoRA. Until 2019, EMIS data stated that there were 25 of MANIC. All of MAN IC is a genus and species of MAN that from the beginning were designed to achieve the nation's strategic aims and objectives. Managed based on quality, this educational institution has been carefully designed from the start to meet - even exceed - national education standards. Therefore, MAN IC has special criteria in recruiting principals, teachers, education staff and students. The four parties above are essential, not substitutive nor complementary, which supports the achievement of the vision and mission of MAN IC in producing high quality 
alumni. This article seeks evidence that the quality of madrasas, principals, teachers and student input and psycological capital affect student quality.

\section{Theoritical Framework}

\subsection{Output: Student Achievement}

The quality of madrasas is measured by the achievements of students and their alumni who can compete by being accepted at high quality universities at home and abroad. Discussion in Indonesia today, academic achievement or academic performance of students becomes material research policy for the size of high quality alumni. Especially madrasa. The prevalent indicator is mainly due to the status of private madrasas, most of which lack quality but provide educational services to students from poor families (Kendra, 2019) with high academic achievement. Academic achievement is the result of learning from a learning activity carried out based on measurements and assessments of the results of learning activities in the academic field which are manifested in numbers or letters (Spinath, 2012). Academic achievement can be in the form of report, UN scores, and various other academic awards.

\subsection{Quality of Madrasah}

What variables can direct student achievement? Because of the influence of regular education at school, courses or precisely because he dropped out of school? Quality school, said Australian Government (2016) is quality outcomes. Formal schooling systems throughout the world are founded on the assumption that schools make a positive contribution to the ability of student's skills. Anders (2018) mentions educational goals, psychological levels, pedagogical designs, teachers and curriculum designed as part of the promises inherent in formal schools based on a strong theoretical basis. In formal schools multidimensionally designed to lead scientific literacy. In the formal school system, according to Moller (2004: 154), students are accustomed and trained to develop applicable, integrated and consistent knowledge. Students are accustomed to doing experiments, removing old ideas and then replacing them with new findings. Test new ideas, then express and apply them in various situations and contexts. Collaborative learning and thought processes designed within study groups in formal school classes play a very important role. Meanwhile Glasser (1990) mentioned that there are no more students who can work with high quality in their regular academic classes. Regular classes full of control (McNeil, 1986, Glasser, 1986) actually make students unable to productive and innovative work called Tribus (1988) as an indicator of working with high quality. Marsh and Yeung (2019) mentioned that academic achievement or academic performance is influenced by school-based performance and academic self-concept. Also influenced by the implementation of character education, student behavior (Skaggs and Bodenhorn, 2006).

\subsection{Leadership of Madrasah Principle}

Sebagai principle madrasah, fungsi leadership and management nya dipercaya secara luas berpengaruh langsung terhadap mutu school. The principal's leadership style called Odeyemi (2010) influences teacher's job performance. Karatas (2019) refers to professionalism as one of 
the principals of leadership and management of school principals. The MoRA launched a program of continuing professional development (Pengembangan Keprofesian Berkelanjutan, PKB) for madrasa heads to hone their competence and professionalism on an ongoing basis. The madrasa head, not only must have certain qualifications but also must have personality, managerial, entrepreneurship, supervision and social competence (PMA 58/2017). Not enough with that, school principals in Indonesia are also required to attend training as part of the certification program. Condon \& Clifford's report (2012) states that school principle performance is influenced by qualifications, competencies and certifications. The combined qualifications, competencies and certifications are designed as a guarantee for the implementation of education and management of madrasas to run effectively, efficiently and accountably in carrying out their duties in managerial, entrepreneurial, and supervision aspects of teachers and education staff (PMA 58/2017). The managerial task of the madrasa head with special mandates such as MAN IC, Hoadly and Galant (2016) emphasizes the management of madrasa organizations. By consolidating the standards of educators and education personnel (Friedrich, 2013), funding, infrastructure and governance in national education standards. Entrepreneurship is intended to develop the madrasa ecosystem. Arman, Thalib and Manda's (2016) research that the supervision of school supervisors (PMA 2/2012), the competency of school principals and their motivation can improve the quality of teacher performance.

\subsection{Psychological Capital and Professional Teacher}

The teacher is a professional educator with the main task of educating, teaching, guiding, directing, training, evaluating, and evaluating students in Madrasas (PMA 58/2017). The MAN IC teacher is selected and the rigor in the selection is intended so that competent teachers are selected and their performance is good (Jacob, et. Al., 2018). Sirait's (2016) empirical research in Indonesia reinforces the research of Goldhaber (2002), Rockoff (2004), Kukia-Acevedo (2009) that teacher quality influences student achievement. According to Aaronson, Barrow and Sander (2007) teacher quality is important for lower-ability students. Professional teachers tend to prepare themselves as best they can by preparing lesson plans, learning materials, and good learning resources so that the so-called Kukia-Acevedo (2009) affects the GPA index (indeks prestasi akademik, IPK) in their mathematics subjects. The step of the teacher who trains students in mathematics is called Campbell and Malkus (2011) also affect student achievement. Mathematics training that takes place at school functions to develop the teacher's leadership role and presents at the school location mathematics material (Dunekacke, Jenben \& Blömeke, 2014), pedagogy, and curriculum design as a form of professional collaborative development aimed at increasing mathematics learning and increasing student achievement.

Anders (2018) developed quality criteria for science teaching consisting of 10 criteria to identify teaching and learning in the classroom. Namely, make nature "questionable", incorporate prior knowledge, develop experiments together with the children, practice working in a precise way, foster scientific discourse, use models and representations, take the social and historical embeddedness of scientific phenomena into account, point out the science is open to change, ensuring learning gains and facilitating perceived self-efficacy. Chen's research (2018) self-efficacy made a positive contribution to the learning performance of laboratory-based science teachers, in addition to emotional intelligence.

\subsection{Student Input and Teacher-Student Engagement}


Although MAN IC students are selected with very competitive, Cardwell (2011) cautions that engaging teenage students is challenging because their motivation has dropped dramatically from elementary schools, junior high schools to senior high schools or Madrasah Aliyah. Based on Warren and Hale's (2016) research that teacher guidance services to students contribute to student success, especially to teachers who have high self-efficacy beliefs. This guidance service is a form of teacher-student engagement, not only aims to maintain the spirit of learning, improve student achievement, according to Taylor, Leah \& Parsons (2011) especially focusing upon disengaged students (who are not learning) to engaged learners (who are learning).

As an elite madrasa and a high level of workload, however, MAN IC teachers certainly have job satisfaction or dissatisfaction that affects their performance (Afshar and Doosti, 2016; Ordu, 2016; Razee, et. al., 2018), in addition to happiness, subjective well- being and creativity (Jalali and Heidari, 2016). Emotional intelligence, called Corcoran and Tormey (2013), is the predictor of predicting student teacher's performance. Based on the empirical facts, MAN IC teachers will be disrupted their performance in teacher-student engagement if the work experiences burn out. Schaufeli et. al., (2002) mentioned that symptom burn out includes feeling exhausted due to heavy burden, experiencing cynical attitude and detached attitude toward work and feeling incompetent as a teacher.

\section{Method}

The designof this study uses Creswell's narrative design (2019: 501-511), in which there are three dimensions in the narrative structure: namely personal and social interactions, continuity between what happened in the past, present and future and the developing situation. Out of 25 , only 17 MAN ICs will be identified by the leadership role of the madrasa head in carrying out two things: creating a madrasa environment by making himself a role model, conducting academic and non-academic supervision, leading the quality of internal and external madrasas. This last point is included in preparing important documents. Such as the madrasa medium term plan (rencana jangka menengah madrasah,RJMM), the madrasa annual plan (rencana tahunan madrasah, RTM) and how the teacher arranges the midterm plan (rencana tengah semester, RTS), prepares the supervision plan and its implementation as well as various other policies such as admission of new students, determination of graduate competency standards, preparation of material and teaching materials, classroom learning processes, and curricular, intra-curricular and extra-curricular programs. It also includes the policy to increase the qualifications and competencies of teachers and education personnel in supporting the quality of human resources and the quality of madrasas as educational units. The average achievement of UN scores and the distribution of alumni to tertiary and domestic tertiary levels will be a benchmark for the internal quality of madrassas, between madrassas and madrassas with regular madrassas at the same level. Data in the form of documents and reports from each madrasa will be tabulated, analyzed and compared.

\section{Results and Discussion}

Madrasa quality variables can be identified throughmadrasa quality report (Rapor Mutu Madrasah, RMM) and accreditation status. RMM is measured by the instrument of Education 
Quality Assurance (Penjaminan Mutu Pendidikan, PMP). For madrasas, the RMM can be used as a baseline for madrasah development over the next 4 years called the RPJMM. With a certain scale, it will be seen which items on the weak RMM, which are priorities to be increased, will also see items with high RMM scores to be maintained or increased further. The RPJMM document is used as a reference in preparing the Madrasa Annual Development Plan (Rencana Pengembangan Tahunan Madrasah, RPTM) complete with the required budget called the Madrasah Budget and Expenditure Plan (Rencana Anggaran dan Belanja Madrasah, RABM). Hanushek's (1998) research proves that school expenditure affects school performance. Therefore, based on the RMM and RPJMM documents, the RPTM and RABM above the head of the madrasa can build a madrasah internal quality assurance system (Sistem Penjaminan Mutu Internal, SPMI) as well as a guide for him to lead and manage his institution. This SPMI determines external quality assurance system (Sistem Penjaminan Mutu Eksternal, SPME) which is marked by accreditation status.

Table 1. Accreditation Status of MAN IC

\begin{tabular}{ccc}
\hline No & Accreditation Status & Total \\
\hline 1 & A & 13 \\
2 & B & 6 \\
3 & Not Acredited (New) & 6 \\
\hline
\end{tabular}

Data is processed from the KSKKM Directorate and official information from the respective website of IC MAN.

From 25 MAN ICs, there are 13 institutions that have A accreditation status from BAN S/M, 6 institutions with B accreditation status, while the remaining 6 institutions have not been accredited because they are new. Thus 19 institutions that have met national Education standards based on PP 13/2015 consisting of graduate competency standards, content, processes, educators and education personnel, facilities and infrastructure, management, education funding and education assessment, when assessed by BAN assessors $\mathrm{S} / \mathrm{M}$ with a very good quality status.

With excellent and superior accreditation status, the next question is, what is it influenced by? First of all it can be seen in the profiles of madrasah principals according to their academic levels. According to PMA 24/2018, among the many requirements to become a madrasa head, it is not explained in detail about the level of education. However, because MAN IC is one of the pilot projects that was born from the strategic policy of the Ministry of Religion, the madrasah head candidate must have high qualifications and competencies, different from other leading madrasas or even regular regular madrasas in general.

Table 2. Academic Degree of Principle of MAN IC

\begin{tabular}{ccc}
\hline No & Academic Degree & Total \\
\hline 1 & Dr & 16 \\
2 & Magister & 9 \\
3 & Bachelor & 0 \\
\hline
\end{tabular}

Data is processed from the KSKKM Directorate and official information from the respective website of IC MAN.

In Table 2 it is mentioned about the academic title of the head of MAN IC. A total of 16 madrasa principals have doctoral degrees, the rest are masters. There is no one who only has a bachelor's degree. Then how is the composition of the head of MAN IC of gender? The following table explains it. 
Table 3. Gender Status of Principle of MAN IC

\begin{tabular}{ccc}
\hline No & Status Akreditasi & Jumlah \\
\hline 1 & Male & 16 \\
2 & Female & 9 \\
\hline
\end{tabular}

Data is processed from the KSKKM Directorate and official information from the respective website of IC MAN.

Table 3 shows that the composition of MAN IC principle by sex is 16 males, while the remaining 9 are females. According to PMA 16/2020 all principle of MAN IC in working accompanied by the madrasa committee, in carrying out their duties, among others, designing madrasa quality architecture and managing budget allocations. Then what about the composition of the MAN IC teacher can be seen in the following table.

Table 4. Academic Degreeof Teacher of MAN IC

\begin{tabular}{|c|c|c|}
\hline No & Academic Degree & Total \\
\hline 1 & 0. & 8 \\
\hline 2 & Magister & 109 \\
\hline 3 & Bachelor & 43 \\
\hline & Total & 160 \\
\hline
\end{tabular}

Data is processed from the KSKKM Directorate and official information from the respective website of IC MAN.

In table 4 it can be seen that the average MAN IC teacher is a master alumni, with 109 teachers, followed by bachelor with a total of 43 people and a doctoral level with 8 teachers. Once again, this is a very good counterbalance, that MAN IC teachers have taken very good levels of education to teach high school students.

Table 5. Gender Statusof Teacher of MAN IC

\begin{tabular}{cllc}
\hline No & & Gender Status & Total \\
\hline 1 & Male & & 117 \\
2 & Female & & 43 \\
\hline & & Total & 160 \\
\hline
\end{tabular}

Data is processed from the KSKKM Directorate and official information from the respective website of IC MAN.

Table 5 states that there are more male teachers than female teachers. In a boarding education system, where the teacher not only acts as a teacher but also as parents and caregivers, then the balance does have an impact on the mental development of students. Male teachers who reflect fatherhood will be more suited to female students, while female teachers who reflect matherhood will have an impact on the mental development of male students.

Table 6. Teacher Certificationof MAN IC

\begin{tabular}{clc}
\hline No & Certification Holder & Total \\
\hline 1 & Certified & 113 \\
2 & Not Certified & 47 \\
\hline
\end{tabular}




\begin{tabular}{lc}
\hline Total & 160 \\
\hline
\end{tabular}

Data is processed from the KSKKM Directorate and official information from the respective website of IC MAN.

In Table 6 it is explained that MAN IC teachers who have received educator certificates and received teacher certification allowances are 113 people, while the remaining 47 teachers have not. Teacher certification is indeed a sign that the teacher is not only competent in accordance with PMA 43/2014, but is also designated as a professional teacher. All MAN IC teachers who have been certified are civil servants, while the rest are non-PNS permanent teachers who are paid with special allowances. In accordance with KMA 103/2015 regarding the fulfillment of the workload of Madrasa teachers who are certified by educators, the KMA 890/2019 regulates the workload of Madrasa teachers. Besides that, along with the rampant potential of radicalism in educational institutions, PMA 2/2020 was published on strengthening character education in madrassas, which is integrated between religion and Pancasila. Character education is also one of the tasks of the teacher. One of them is so that religious moderation becomes the main stream in madrasa lessons (Saifuddin, 2019), as stated in the RPJMN 2019-2024.

As part of their professional assignments, teachers who teach science majors also plan learning programs in the fields of science, math, physics, chemistry, and biology and english. While the teachers majoring in social studies designed plans for learning programs in Indonesian, math, sociology, geography, economics and english. All teachers who teach religion, arabic, history, etc., also prepare lesson plans. All RPPs include other important things such as learning materials, learning resources, laboratory and learning media, class approach and management, and learning evaluation. The progress of student learning progress is tabulated and recorded in the report card, which also records the intra-extracurricular activities participated by students. Then, what is the ratio between PNS teachers and non-PNS teachers, it can be seen in the following table.

Table 7. Employment Status of Teacherof MAN IC

\begin{tabular}{clc}
\hline No & \multicolumn{1}{c}{ Employment Status } & Total \\
\hline 1 & Permanent civil servants (PNS) & 124 \\
2 & Non-PNS Permanent Employees & 33 \\
3 & Non Permanent & 3 \\
\hline \multicolumn{2}{c}{ Total } & 160 \\
\hline
\end{tabular}

Data is processed from the KSKKM Directorate and official information from the respective website of IC MAN.

Table 7 states that there are 124 registered PNS teachers, while non-PNS permanent teachers are 33, while non-permanent teachers are 3. By comparing tables 6 and 7, it appears that the average PNS teacher has been certified. While non-PNS permanent teachers and non-permanent teachers tend not to be certified. The data tend to assume that those who are certified have the competence and performance as professional teachers who are assessed regularly every semester and on an ongoing basis. The teachers are not only involved in the classroom, in the laboratory, library and madrasa environment, but also engage with students in the dormitory building for the development of student interest talents. The madrasah head also supervises teachers starting from checking the planning documents, implementing them to evaluating learning. 
Table 8. Supervision of Principle of Madrasah

\begin{tabular}{cccccc}
\hline No & Jenis Supervisi & \multicolumn{3}{c}{ Frekwensi } & \\
& & Jarang & Jarang & Sering & Sering \\
& & Sekali & & & Sekali \\
\hline 1 & Akademik & & $\mathrm{X}$ & $\mathrm{X}$ \\
2 & Non Akademik & & $\mathrm{X}$ & $\mathrm{X}$ \\
\hline
\end{tabular}

Data is processed from the KSKKM Directorate and official information from the respective website of IC MAN.

Table 8 shows that principals not only conduct academic supervision of teachers but also non-academic supervision of madrasa administrative staff. Supervision is intended so that the performance of teachers in the teaching and learning process is in accordance with the vision, mission, mandate and objectives of the madrasa, as well as that the madrasa administration staff work synchronously and in harmony with academic needs. Then how are the results? From 25, there are 17 MAN ICs majoring in natural sciences and in 2019 all have taken the UN with a list of values as listed in the following table.

Table 9. National Exam Score in Majoring of Natural Sciences

\begin{tabular}{|c|c|c|c|c|c|c|c|c|c|c|c|c|c|c|c|c|c|c|c|}
\hline \multirow{3}{*}{ NO } & \multirow{3}{*}{ MANIC } & \multicolumn{18}{|c|}{ SUBJECTS } \\
\hline & & \multicolumn{3}{|c|}{$\begin{array}{l}\text { INDONESIAN } \\
\text { LANGUAGE } \\
\end{array}$} & \multicolumn{3}{|c|}{ ENGLISH } & \multicolumn{3}{|c|}{ MATH } & \multicolumn{3}{|c|}{ PHYSICS } & \multicolumn{3}{|c|}{ CHEMISTRY } & \multicolumn{3}{|c|}{ BIOLOGY } \\
\hline & & 2017 & 2018 & 2019 & 2017 & 2018 & 2019 & 2017 & 2018 & 2019 & 2017 & 2018 & 2019 & 2017 & 2018 & 2019 & 2017 & 2018 & 2019 \\
\hline 1 & MAN INSAN CENDEKIA SERPONG & 88.3 & 85.7 & 89.8 & 84.9 & 80.6 & 90.6 & 90 & 86.7 & 89.38 & 85.6 & 87.9 & 93.8 & 90.4 & 92.3 & 90.8 & 81.6 & 88.2 & 91 \\
\hline 2 & $\begin{array}{l}\text { MAN INSAN CENDEKIA } \\
\text { GORONTALO } \\
\end{array}$ & 87.2 & 82.7 & 88.2 & 76.8 & 76.7 & 80.3 & 87.8 & 78.8 & 82.69 & 79.3 & 84.9 & 97 & 89.6 & 87.9 & 89.5 & 81.5 & 81.7 & 84.9 \\
\hline 3 & MAN INSAN CENDEKIA JAMBI & 85.5 & 82.3 & 84.5 & 74.6 & 67.1 & 72.6 & 69.2 & 60.3 & 67.02 & 66.1 & 66.2 & 83.9 & 74.3 & 64.1 & 75.5 & 73.5 & 74.7 & 70.7 \\
\hline 4 & $\begin{array}{l}\text { MAN INSAN CENDEKIA } \\
\text { SUMATERA BARAT }\end{array}$ & * & * & 83.7 & * & * & 75.2 & * & * & 69.1 & * & * & 70 & * & * & 77.1 & * & * & 74.9 \\
\hline 5 & $\begin{array}{l}\text { MAN INSAN CENDEKIA } \\
\text { SUMATERA SELATAN } \\
\end{array}$ & * & 79.3 & 81.3 & * & 71.7 & 71 & * & 51.9 & 59.44 & * & 58.5 & 79.5 & * & 69 & 67.1 & * & 71.7 & 68.9 \\
\hline 6 & MAN INSAN CENDEKIA RIAU & $*$ & 81.6 & 82.1 & * & 63.2 & 71.5 & $*$ & 51 & 58.23 & * & 59.1 & 86.8 & $*$ & 72.1 & 79.8 & $*$ & 71.1 & 76.4 \\
\hline 7 & $\begin{array}{l}\text { MAN INSAN CENDEKIA } \\
\text { BENGKULU }\end{array}$ & $*$ & $*$ & 82.5 & $*$ & $*$ & 66.5 & $*$ & $*$ & 47.88 & $*$ & $*$ & 55 & $*$ & $*$ & 62.5 & $*$ & * & 70.5 \\
\hline 8 & $\begin{array}{l}\text { MAN INSAN CENDEKIA BANGKA } \\
\text { BELITUNG }\end{array}$ & * & 82.1 & 82.3 & * & 65.2 & 65.7 & * & 57.6 & 60.7 & * & 43.3 & 54.8 & * & 59.4 & 64.3 & * & 67.8 & 77.5 \\
\hline 9 & MAN INSAN CENDEKIA ACEH & * & * & 73.2 & $*$ & $*$ & 59.5 & * & * & 40.59 & * & $*$ & 43.1 & * & $*$ & 62.1 & $*$ & * & 57.4 \\
\hline 10 & $\begin{array}{l}\text { MAN INSAN CENDEKIA } \\
\text { KEPULAUAN RIAU } \\
\end{array}$ & * & * & 84.6 & * & * & 74.3 & * & * & 59.17 & * & * & 65.8 & * & * & 63.2 & * & * & 71.6 \\
\hline 11 & $\begin{array}{l}\text { MAN INSAN CENDEKIA } \\
\text { PEKALONGAN JATENG } \\
\end{array}$ & * & 86.4 & 87.5 & * & 73.3 & 84.2 & * & 77.7 & 85.04 & * & 77.7 & 96.8 & $*$ & 87.2 & 90.5 & * & 81.4 & 87.4 \\
\hline 12 & $\begin{array}{l}\text { MAN INSAN CENDEKIA TANAH } \\
\text { LAUT KALSEL }\end{array}$ & * & * & 85.1 & * & * & 65.8 & * & * & 50 & * & * & 67.1 & * & * & 59.2 & * & * & 65.9 \\
\hline 13 & $\begin{array}{l}\text { MAN INSAN CENDEKIA } \\
\text { KALIMANTAN BARAT }\end{array}$ & $*$ & * & 80.7 & $*$ & $*$ & 61.8 & $*$ & $*$ & 48.59 & $*$ & ${ }^{*}$ & 64.2 & $*$ & $*$ & 65.9 & $*$ & $*$ & 60.8 \\
\hline 14 & $\begin{array}{l}\text { MAN INSAN CENDEKIA } \\
\text { KALIMANTAN TIMUR }\end{array}$ & * & 81.2 & 84.7 & * & 76 & 64.1 & * & 59.5 & 52.65 & * & 64.2 & 73.5 & * & 68 & 78.9 & * & 75.8 & 78.4 \\
\hline 15 & $\begin{array}{l}\text { MAN INSAN CENDEKIA PAPUA } \\
\text { BARAT }\end{array}$ & ${ }^{*}$ & * & 80.4 & $*$ & * & 49 & ${ }^{*}$ & $*$ & 48.87 & $*$ & * & 58.8 & * & $*$ & 61.7 & * & ${ }^{*}$ & 59.6 \\
\hline 16 & $\begin{array}{l}\text { MAN INSAN CENDEKIA SULAWESI } \\
\text { TENGAH }\end{array}$ & $*$ & * & 80.3 & $*$ & ${ }^{*}$ & 67.9 & * & $*$ & 43.17 & * & * & 51.8 & * & $*$ & 66.3 & * & * & 60.7 \\
\hline 17 & $\begin{array}{l}\text { MAN INSAN CENDEKIA SULAWESI } \\
\text { TENGGARA }\end{array}$ & $*$ & * & 84.2 & * & $*$ & 63.6 & * & * & 51.74 & $*$ & * & 62.9 & * & $*$ & 69.1 & * & ${ }^{*}$ & 68.6 \\
\hline
\end{tabular}

Data is processed from the KSKKM Directorate and official information from the respective website of IC MAN. 1.*there is no class XII yet; 2. Six MAN ICs (Maluku Utara, Sumatera Utara, NTB, Sulawesi Selatan, Jawa Timur and Lampung there are no XII classes in 2019).

Table 9 shows that old-generation MAN ICs, such as Serpong always excel in obtaining average UN results, show good output, compared to new others MAN IC, followed by Gorontalo and Jambi. Riau and Pekalongan quickly followed the quality of Gorontalo and Jambi. While the rest are still far below, even though the average UN results of all MAN ICs, the remaining average is above the regular MAN.MAN ICs majoring in natural sciences who in 
2019 have taken the UN with a list of grades as listed in the Table 9 of natural sciences: can only take 1 elective subject out of 3 electives, namely physics, chemistry and biology. Therefore, the things that must be done by natural science students only follow the UN with english, Indonesian bahasa, math, and 1 elective subject from 3 elective subjects chosen by science students, whether physics, chemistry or biology. By looking at Table 9 the average value of the UN results in biology subjects in MAN IC Serpong in 2019 is 91 . Therefore if we take the conclusion that in a study group there are 35 people, the tendency of this matter that allows students in the group study who chose biology subjects around 20 people. Then the average obtained by students choosing biology subjects gets grades ranging from 86-94. In the case study the average UN score for the lowest biology subject in MAN IC Aceh with a score of 57.9. Therefore if we conclude that there are around 35 people in a group, there is a tendency for those who allow students in the study group to choose biology subjects in the national examination to be around 20 people. Then the average obtained by students choosing biology subjects is scored at around 49-60. Then what about the results of the UN in the social sciences department?

Table 10. National Exam Score in Majoring of Social Sciences

\begin{tabular}{|c|c|c|c|c|c|c|c|c|c|c|c|c|c|c|c|c|c|c|c|}
\hline \multirow{3}{*}{ No } & \multirow{3}{*}{ MANIC } & \multicolumn{18}{|c|}{ SUBJECTS } \\
\hline & & \multicolumn{3}{|c|}{$\begin{array}{l}\text { INDONESIAN } \\
\text { LANGUAGE }\end{array}$} & \multicolumn{3}{|c|}{ ENGLISH } & \multicolumn{3}{|c|}{ MATH } & \multicolumn{3}{|c|}{ ECONOMY } & \multicolumn{3}{|c|}{ SOCIOLOGY } & \multicolumn{3}{|c|}{ GEOGRAPHY } \\
\hline & & 2017 & 2018 & 2019 & 2017 & 2018 & 2019 & 2017 & 2018 & 2019 & 2017 & 2018 & 2019 & 2017 & 2018 & 2019 & 2017 & 2018 & 2019 \\
\hline 1 & MAN INSAN CENDEKIA SERPONG & 88.4 & 82.3 & 88.4 & 83.6 & 83.9 & 89.4 & 96.2 & 70.3 & 81.2 & 89.7 & 87.5 & 98.3 & 90 & 89.3 & 82.8 & 84.9 & 90.9 & 87.8 \\
\hline 2 & $\begin{array}{l}\text { MAN INSAN CENDEKIA } \\
\text { GORONTALO }\end{array}$ & 86 & 82.8 & 87.7 & 75 & 75 & 79.5 & 94.4 & 78.5 & 81.3 & 86.8 & 84.5 & 95.3 & 81.8 & 77 & 78.5 & 88.2 & 84.7 & 85.1 \\
\hline 3 & MAN INSAN CENDEKIA JAMBI & 85.4 & 79.8 & 80.8 & 63.4 & 69.2 & 63.7 & 81.2 & 58.6 & 58 & 82.6 & 78.3 & 76.1 & 86 & 73.4 & 76 & 78 & 85.8 & 83.8 \\
\hline 4 & $\begin{array}{l}\text { MAN INSAN CENDEKIA } \\
\text { SUMATERA BARAT }\end{array}$ & * & * & 84.8 & * & * & 69.7 & * & * & 63.5 & * & * & 74.2 & * & * & 73.6 & * & * & - \\
\hline 5 & $\begin{array}{l}\text { MAN INSAN CENDEKIA } \\
\text { SUMATERA SELATAN }\end{array}$ & $*$ & 75.8 & 77.8 & * & 51.8 & 63.2 & * & 40.4 & 50.1 & * & 66.1 & 76.4 & $*$ & 72.7 & 75.6 & $*$ & 74 & 74 \\
\hline 6 & MAN INSAN CENDEKIA RIAU & * & 81.2 & 79.5 & * & 57.3 & 59.4 & * & 42.4 & 42.8 & * & 75 & 76.8 & * & 72.8 & 71.1 & * & 88 & 80 \\
\hline 7 & MAN INSAN CENDEKIA & * & * & 79.3 & * & * & 65.3 & * & * & 44.7 & * & $*$ & 87.5 & * & * & 75.3 & * & * & 72.7 \\
\hline 8 & $\begin{array}{l}\text { MAN INSAN CENDEKIA BANGKA } \\
\text { BELITUNG }\end{array}$ & * & 81.5 & 83.8 & * & 53 & 63.8 & * & 54.7 & 57.4 & * & 60 & 69 & * & 71.8 & 70 & * & 79.7 & 83.7 \\
\hline 9 & MAN INSAN CENDEKIA ACEH & * & * & 68.7 & * & * & 58.4 & * & * & 33.9 & * & * & 56.4 & * & * & 50 & * & * & 65 \\
\hline 10 & $\begin{array}{l}\text { MAN INSAN CENDEKIA } \\
\text { KEPULAUAN RIAU }\end{array}$ & * & * & 84.7 & $*$ & * & 68.3 & * & * & 58.6 & $*$ & * & 79.6 & * & $*$ & 77.5 & * & * & 80.4 \\
\hline 11 & $\begin{array}{l}\text { MAN INSAN CENDEKIA } \\
\text { PEKALONGAN JATENG }\end{array}$ & * & 85 & 84.5 & * & 71.3 & 72.2 & * & 70 & 69.7 & * & 73.8 & 86.5 & * & 78.3 & 78.6 & * & 87.6 & 83.1 \\
\hline 12 & $\begin{array}{l}\text { MAN INSAN CENDEKIA TANAH } \\
\text { LAUT KAISEL }\end{array}$ & * & $*$ & 83.4 & * & * & 64.8 & * & * & 42.5 & * & * & 69.6 & * & * & 74.7 & * & * & 79.2 \\
\hline 13 & $\begin{array}{l}\text { MAN INSAN CENDEKIA } \\
\text { KALIMANTAN BARAT }\end{array}$ & * & * & 84.3 & $*$ & $*$ & 68 & * & $*$ & 46.8 & $*$ & * & 90 & * & $*$ & 88 & $*$ & $*$ & 80.5 \\
\hline 14 & $\begin{array}{l}\text { MAN INSAN CENDEKIA } \\
\text { KALIMANTAN TIMUR } \\
\end{array}$ & * & 78 & 81 & * & 62.4 & 60.4 & * & 57.4 & 45.8 & * & 75 & 78.2 & * & 75.3 & 75 & * & 69 & 87.3 \\
\hline 15 & $\begin{array}{l}\text { MAN INSAN CENDEKIA PAPUA } \\
\text { BARAT }\end{array}$ & * & * & ** & * & * & ** & * & * & ** & * & * & ** & * & * & ** & * & * & ** \\
\hline 16 & $\begin{array}{l}\text { MAN INSAN CENDEKIA SULAWESI } \\
\text { TENGAH }\end{array}$ & * & * & 82.8 & * & * & 68.2 & * & * & 43.5 & * & * & 68.8 & * & * & 69.3 & * & * & 68 \\
\hline 17 & $\begin{array}{l}\text { MAN INSAN CENDEKIA SULAWESI } \\
\text { TENGGARA }\end{array}$ & * & * & 83.1 & * & * & 55.4 & * & * & 47 & * & * & 77.5 & * & * & 82.2 & * & * & 75.5 \\
\hline
\end{tabular}

Data is processed from the KSKKM Directorate and official information from the respective website of IC MAN.1.*there is no class XII yet; 2 . **there is no majoring in social science; 3 . Six MAN ICs (Maluku Utara, Sumatera Utara, NTB, Sulawesi Selatan, Jawa Timur and Lampung there are no XII classes in 2019).

Table 10 shows that of the 25 MAN ICs, only 15 were in 2019 where their students had taken the UN. MAN IC Serpong excels followed by East Kalimantan, Gorontalo, Jambi, Bangka Belitung and Pekalongan. Compared with the average UN score of students majoring in natural sciences in Table 9, the average UN score of students majoring in social sciences is higher in all MAN ICs. 
As for the UN scenario for students majoring in natural sciences, in the social sciences major, students can only take 1 elective subject from 3 elective subjects, namely economics, geography and sociology. Therefore, social studies students can only take the national examination with english, Indonesian, math and 1 elective subject from 3 existing elective subjects. By looking at Table 10 it can be seen that the average UN score in geography subjects in MAN IC Serpong reaches 87.8. Therefore if we conclude that there are around 35 people in a group, there is a tendency for that to allow students in the study group to choose about 20 geography subjects. Then the average obtained by students choosing geography subjects was scored at 79-90. In the case study the lowest UN geography subjects can be mentioned is the MAN IC Aceh with a mean of 65 . Therefore if we conclude that there are 35 people in a study group, there is a tendency for those who allow students in the departmentto choose geography subjects around 20 people. Then the average obtained by students choosing geography subjects is around 55-70.

Both students of the natural sciences and social sciences, the UN score is the initial capital for them to choose a university to be a place of study at the next level. The higher the UN score that they achieve, the higher their chances of entering the favorite universities.

Table 11. Destination University of Alumni of MAN IC

\begin{tabular}{ccc}
\hline No & University Destination & Average/Year \\
\hline 1 & Domestic Favorite universities & $81 \%$ \\
2 & Foreign Favorite universities & $19 \%$ \\
\hline & Total & $100 \%$ \\
\hline
\end{tabular}

Data is processed from the KSKKM Directorate and official information from the respective website of IC MAN.

Table 11 can be seen that the majority of MAN IC alumni were accepted at favorite domestic universities, around $81 \%$ compared to $19 \%$ who continued their study abroad. Thus, $100 \%$ of MAN IC alumni continue their studies to the next level. Then which domestic favorite universities are the choices of MAN IC alumni?

Table 12. Domestic FavoriteUniversitiesChosen by Alumni of MAN IC ++

\begin{tabular}{cccccccccccc}
\hline No & Domestic & \multicolumn{10}{c}{ Year } \\
\cline { 3 - 11 } & Universities & $\mathbf{2 0 1 0}$ & $\mathbf{2 0 1 1}$ & $\mathbf{2 0 1 2}$ & $\mathbf{2 0 1 3}$ & $\mathbf{2 0 1 4}$ & $\mathbf{2 0 1 5}$ & $\mathbf{2 0 1 6}$ & $\mathbf{2 0 1 7}$ & $\mathbf{2 0 1 8}$ & $\mathbf{2 0 1 9}$ \\
\hline 1 & ITB & $\mathrm{X}$ & $\mathrm{X}$ & $\mathrm{X}$ & $\mathrm{X}$ & $\mathrm{X}$ & $\mathrm{X}$ & $\mathrm{X}$ & $\mathrm{X}$ & $\mathrm{X}$ & $\mathrm{X}$ \\
2 & $\mathrm{UI}$ & $\mathrm{X}$ & $\mathrm{X}$ & $\mathrm{X}$ & & $\mathrm{X}$ & $\mathrm{X}$ & $\mathrm{X}$ & $\mathrm{X}$ & $\mathrm{X}$ & $\mathrm{X}$ \\
3 & $\mathrm{IPB}$ & & & & & $\mathrm{X}$ & $\mathrm{X}$ & $\mathrm{X}$ & $\mathrm{X}$ & $\mathrm{X}$ & $\mathrm{X}$ \\
4 & UGM & & $\mathrm{X}$ & $\mathrm{X}$ & & & $\mathrm{X}$ & $\mathrm{X}$ & $\mathrm{X}$ & $\mathrm{X}$ & $\mathrm{X}$ \\
5 & Favorite & & & & & & & $\mathrm{X}$ & $\mathrm{X}$ & $\mathrm{X}$ & $\mathrm{X}$ \\
& Islamic & & & & & & & & & & \\
& University & & & & & & &
\end{tabular}

Data is processed from the KSKKM Directorate and official information from the respective website of IC MAN.

Table 12 shows that since MAN IC graduated in 2010, universities such as ITB, UI and UGM became their study goals at the next level. While in the last five years, variations in their study objectives have been more varied. This data is in line with Hayadin's research (2019), the tendency of $85 \%$ of MAN IC Serpong alumni to continue their studies to secular universities, very few of them continue to Islamic universities $(1 \%)$ or pesantren $(1 \%)$. The reason why most students choose the top 10 universities in Indonesia is because there is a large output and 
educational program that matches their majors in high school. So that, it affects the standards of the students themselves.

\begin{tabular}{|c|c|c|c|c|c|}
\hline No & Name & Entry Year & University & Departement & Degree \\
\hline & Melinda Fitriani Arbie & 2012 & Nanyang Technological University (NTU) Singapore & Asian studies (Rajaratnam school of international studies) & Master \\
\hline \multirow[t]{2}{*}{2} & Muhammad Rizqie Arbie & 2012 & aix-Marseille Universite, Franch & Physics aix & Master \\
\hline & & 2012 & aix-Marseille Universite, Franch & Mechanics and Physics offluids & Doctor \\
\hline \multirow[t]{3}{*}{3} & Sahrul Pasisingi & 2005 & Hachinohe National College of Technology & Electrical Engineering & Diploma \\
\hline & & 2007 & University of Electro Communication & Electrical Engineering & Bachelor \\
\hline & & 2010 & University of Electro Communication & Information and Communication Technology & Master \\
\hline $4 \mid$ & Ircham Novianto & 2001 & Monbuka Gakusho, Japan & & Diploma \\
\hline 5 & Umar Hasni & & LIM Kok KWIN Malaysia & Finance & Bachelor \\
\hline 6 & Auditya Herdana & & Sunway College Malaysia & & Bachelor \\
\hline \multirow[t]{2}{*}{7} & Rangga Tri Nugraha & 2016 & International Islamic University Malaysia & Political science (international relation) & Bachelor \\
\hline & & 2019 & Corvinus University of Budapest, Hongaria & Main international relations (diplomacy) & Master \\
\hline 81 & Husain Ali Yahya & 2017 & International Islamic University Malaysia & English for international communication & Bachelor \\
\hline 9 & Salma Auriga Azhar & 2018 & International Islamic University Malaysia & Tourism Planning and hospitaly management & Bachelor \\
\hline 10 & Endang rahmat & 2018 & Univ OST Kioz Korea & & Master-doktor \\
\hline 11 & Fuad Azminuddin & 2017 & Korean Institute of Ocean Ccience and Technology & Oseanografi & Master-doktor \\
\hline 12 & Helsi Rismiati & 2019 & Seoul National University & Internalmedicine & Master \\
\hline 13 & Raditya mobiliu & 2019 & National of Taiwan University of science and technology & Faculty of Engineering,materials science and technology & Master \\
\hline 14 & Fajrin Rahman & 2015 & University of Southern California & & Master \\
\hline 15 & Mukhlis Polin & & University of Auckland New Zealand & Informatin system, School of bussiness & Master \\
\hline 16 & Ika Damayanti Puasa & & Leipzig University, Germany & & Bachelor \\
\hline 17 & Kardina Miranda Bowta & & Marthin Luther Universitat Halle Wittenberg & Biochemie & Bachelor \\
\hline \multirow[t]{3}{*}{18} & Isyna Izzal Muna & & Universita Deglistudi Dell Aquila & Scientific Computing & Master \\
\hline & & & Gdansk University of Technology Polandia & Nanotechnologyand Material Science & Doctor \\
\hline & Marwa Nailul Muna & 2019 & $\begin{array}{l}\text { Rheinisch-Westfälische Technische Hochschule (RWTH) } \\
\text { Aachen University, Jerman }\end{array}$ & Aerospace Engineering & Summer Projec \\
\hline 20 & Andi & & Germany & & Bachelor \\
\hline 21 & Imelda Zahra Elnaz Putri & & Germany & & Bachelor \\
\hline 22 & Hilda Farida & 2018 & Erciyes universitesi, Turkey & & Master \\
\hline 23 & Muhammad Hasan Bashari & & Germany & & Master \\
\hline 24 & Akbar putra Baculu & 2006 & Universitas Utara Malasia & Bachelor of Information Technology UUM & Bachelor \\
\hline 25 & Muhammad Taufan Arsyad & 2006 & Universitas Utara Malaysia & & Bachelor \\
\hline 26 & Abdullah AzzamBishri & 2017 & Islamic University, Madinah & Faculty of Islamic Law (Syariah) & Bachelor \\
\hline 27 & Fida' Azzam Madania & 2017 & Islamic University, Madinah & Faculty of Dakwah and Ushuluddin & Bachelor \\
\hline 28 & Muhammad Fajrin Adnan & 2015 & Islamic University, Madinah & Faculty of Islamic Law (Syariah) & Bachelor \\
\hline 29 & Izzy Granari & 2019 & Islamic University, Madinah & Faculty of Islamic Law (Syariah) & Bachelor \\
\hline 30 & Salwa Minhatul Maula & 2018 & Al Azhar Unibversity, Egypt & Arabic Language & Bachelor \\
\hline \multirow[t]{2}{*}{31} & Nevy Rahmi Nurjana Mohune & 2008 & Universiti Tenaga Nasional Malaysia & & Bachelor \\
\hline & & 2013 & Universiti Kebangsaan Malaysia & & Master \\
\hline 32 & Sulastri Arsad & 2011-2012 & 2 Universite de Bretagne Franch & Biotechnology marine science & Master \\
\hline 33 & Purna Wijaya Menu & 2019 & University of China & Mdical Science & Bachelor \\
\hline 34 & Nurlaila Arbie & 2012 & Virginia Technology, USA & Civil Engineering & Master \\
\hline 35 & Rizal Al Idrus & 2017 & Coventury University, England & & Master \\
\hline \multirow[t]{2}{*}{36} & Fatimatuz Zahro Niam & 2016 & Coventry University London & International Financeand accounting & Bachelor \\
\hline & & & Kings College London & Msc Accounting, Accountability and Financial Managemen & Master \\
\hline 37. & Yudhistira Arsyad & & Universiti Utara Malaysia & Pharmacy & Bachelor \\
\hline 38 & Siti Farah Rahmawati & & Maastricht University, Belanda & Pharmacy & Doctor \\
\hline 391 & Moh Takdirsyah Pomalingo & & Universiti Utara Malaysia & & Bachelor \\
\hline 40 & Sukma Impian Riverningtyas & & University of Leeds, London & Climate Change and Environmental Policy & Bachelor \\
\hline 41 & Qonita Kurnia Andjani & & Queen's University Belfast UK & School of Pharmacy & Master \\
\hline 42 & Safrul Setiawan & 2017 & University of Tokyo & system innovations & Master \\
\hline \multirow[t]{2}{*}{43} & Namira Samir & 2015 & Durham University London & Islamic Finance Management & Master \\
\hline & & & London School of Economic and political science & Human Geography and urban studies & Doctor \\
\hline 44 & Muhammad Alfiyan Zubaidi & & Tokyo University, Japan & & Master \\
\hline 45 & M. Adhli Al Karni & & Al - Qarawiyyin University, Fes Maroko & & Bachelor \\
\hline
\end{tabular}

Fig.1. Distribution of MAN Alumni at Foreign Universities

Data is processed from the KSKKM Directorate and official information from the respective website of IC MAN.

By taking the UN, until 201917 MAN IC has had alumni who continue their studies at reputable universities, both domestically and abroad. In Table 13 it is stated that alumni majoring in Science IC MAN IC take the next level in the basic sciences, medical science, engineering, finance, kalanging, biokomia, science and technology, marine science, etc. 


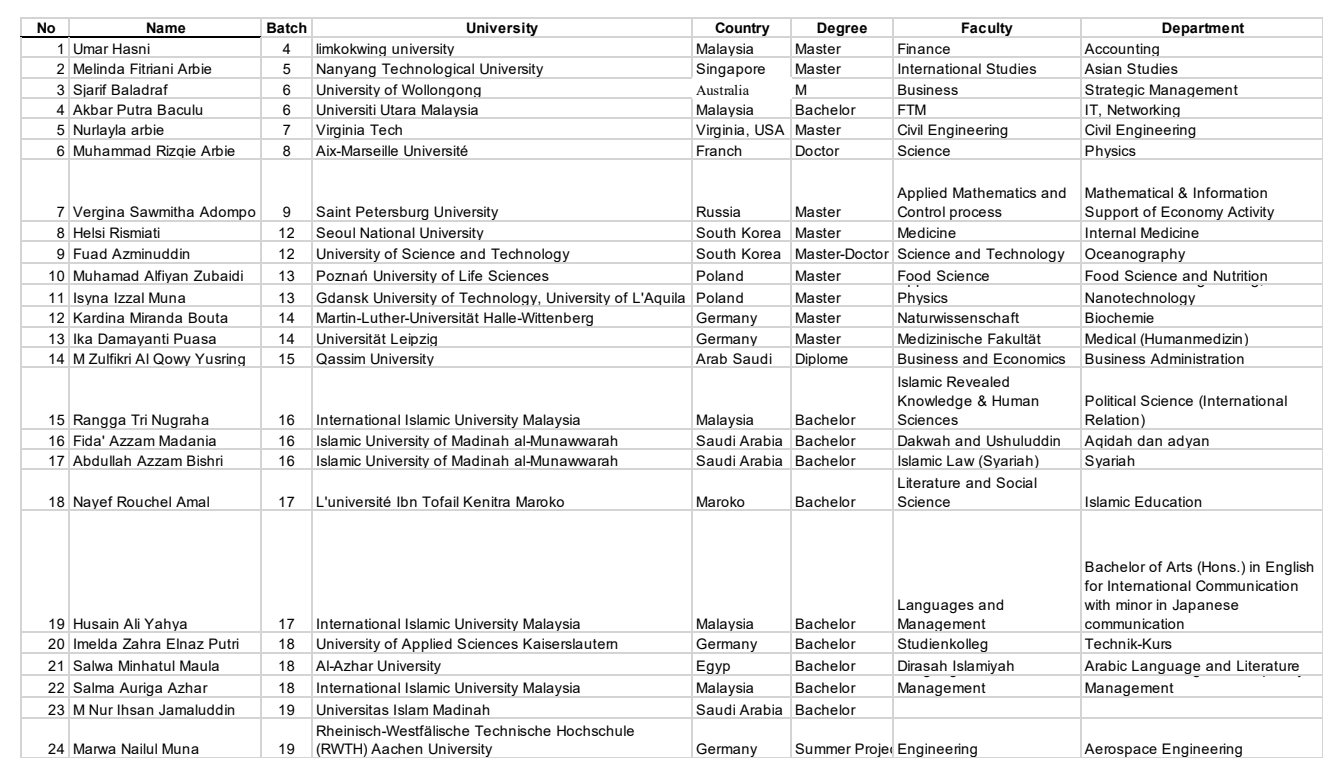

Fig.2. Distribution of MAN Alumni at Foreign Universities

Data is processed from the KSKKM Directorate and official information from the respective website of IC MAN.

Tables 13 and 14 show data that alumni majoring in social sciences undertook further studies at foreign universities in the fields of religion, language, international relations, politics, Islamic law, geography, urban studies, communication, psychology, finance, sociology and anthropology, business and management, and education. While students majoring in natural sciences choose foreign universities mostly choose the countries of Germany, Japan, the Netherlands, Korea, and Singapore, etc. because of modern science and technology considerations. While students majoring in social science prefer Middle Eastern countries, the United Kingdom, Australia, France, Malaysia, etc., because universities in these countries are more advanced in achieving more advanced social and religious studies.

One thing that stands out from the choice of MAN IC alumni to high-reputed universities domestically and abroad is the consideration of large outputs. That is something that is high in reputation and recognition in terms of quality so that it can influence students to choose various universities. As an example is the distribution of competing university alumni, international networks, good and attractive educational programs, good achievements, reputation and recognition in the achievement of the latest knowledge and findings, scientific work that is lined up and career decision orientation that is deemed to guarantee.

MAN IC students' achievements from the beginning were designed with high quality standards, because the principal, teachers, budget, education staff, and students were recruited strictly. Because it was designed as a semi-pesantren, the leadership style of the head of MAN IC also plays a role (Adeyemi, 2010). Ross and Gray's (2006) research mention the principal's transformative leadership triggering teacher commitment to organizational values. But apparently there are differences between one IC MAN with another. If the alumni quality measure is the UN score, then the average UN MAN IC score is not the same, some are at 90, 80,70 , even 60 , even though the results of the UN every year show a tendency to increase. MAN IC Serpong always excels because of its long age, therefore, it has a long experience to build academic and scientific traditions in their teaching and learning process. 
As in other madrasas, the principle of MAN IC is incorporated in the Madrasah Principle Working Group (Kelompok Kerja Kepala Madrasah, KKM), in order to increase sharing of experiences between them, while MAN IC teachers are incorporated in the Subject Teachers' Conference (Musyawarah Guru Mata Pelajaran, MGMP) as their learning community. Generally teachers join the MGMP together with other teachers who live in the district/city or sub-district area. Among other things, by joining the MGMP, teachers are in a continuous professional development (PKB) program. Kein (1998) mentions that the involvement of teachers and their peers influences student achievement.

Regarding the allocation of funds, Hanushek's (1998) research states that variations in school expenditure do not always consistently affect school performance. Teacher quality is also not only influenced by their educational background, teaching skills, years of service and the size of the number of students in the class, but by incentives and salaries as compensation paid to them. The Government of Indonesia has adopted a policy that certain teachers can be given additional allowances other than salaries after they have been determined as professionals through certification (Law 14/2005). However, Ha and Sung's research (2011) in South Korea, the certification program in Indonesia was welcomed by teachers with enthusiasm. Golhaber and Brewer's (2000) research proves that certification has a systematic effect on student achievement. With certification, teachers get monetary rewards (Bello and Jakada, 2017) and good compensation (Papilaya, Taukora, and Rijal, 2019) that affect their performance.

After the teacher certification program absorbed a large budget to pay their allowances despite Duckworth's research, Quinn and Seligman (2009) proved that the benefits due to certification and competence did not increase teacher professionalism, student achievement and school quality. After the evaluation, the teacher certification program is no longer portfolio based but through Teacher Training Education (Pendidikan Pelatihan Guru, PPG, PP 74/2008). Through PPG, teacher competencies consisting of pedagogic, personality, social, and professional (Permendiknas 16/2007 and article 30 paragraph (4) PMA 90/2013) are trained and honed to be prepared to become professional teachers. The training is expected to foster positive trait, grit (Duckworth, 2017), life satisfaction as proven by Duckworth, Quinn and Seligman (2009) effect on teacher effectiveness. In Germany, Blömeke et al. al, (2015) called professional training successful. Professional and competent teachers according to Rahmatullah (2016) and Sumantri \& Whardan (2017) research have an effect on teacher performance. Likewise Santin and Sicilia (2017) research in Spain.

All madrasa teachers are civil servants (PNS) whose rights and obligations are strictly regulated by PNS discipline (PP 53/2010). Madrasa teachers follow the charitable culture of charity as the value of the MoRA, in addition to the five work cultures: integrity, professionalism, innovation, responsibility and example. They also teach Islamic religious values in addition to the four pillars of nationality: Pancasila, NKRI,1945 Constitution and Bhinneka Tunggal Ika (PMA 183/2019, 184/2013). According to Schaufeli, et. al, (2002), a teacher who experiences engagement in carrying out his assignments in class will be vigor, dedication and absorption. Klassena, Yerdelen and Durksen (2013) state that teacher management both physically, cognitively, emotionally, socially and with colleagues will open the possibility that all students who are in their teenage phase have full access to it. Teachers who are highly engaged in their work open crucial access to stimulate student engagement at school. The issue of teacher-student engagement is the theme of debate and the latest research in education which is very critical (Economist Intelligence Unit, 2012; Pianta, Hamre, \& Allen, 2012; Rimm-Kaufman \& Hamre, 2010; Staiger \& Rockoff, 2010).

Teachers are required to prepare a learning plan in which 4 national education standards are listed: translating graduate competency standards - in which core competencies are contained - 
in the form of basic competencies, contents, processes and assessments. This is in accordance with Friedrich (2013: 96), Dewi, Bundu and Tahmir (2016) noted the following indicators as a measure of teacher performance: 1) the ability to make the planning and preparation of teaching; 2) the mastery of the material taught to students; 3 ) the mastery of teaching methods and strategies; 4) the ability to give assignments to students; 5) the ability to manage students; and 6) the ability to conduct appraisals and evaluations. The MoRA policy on these 4 standards is referred to as teacher autonomy, so that each teacher will measure workload, work life balance to produce good job performance (Johari, Tan, Tjik, Zulkarnain, 2018). With the learning plan, the teacher prepares teaching materials, implements the teaching and learning process, and runs an evaluation. With the characteristics of such work, teachers will be increasingly involved in their duties and obligations, and it affects their performance (Johari and Yahya, 2016).

In carrying out their teaching assignments, teachers are supervised academically by the principal (PMA 58/2017). This supervision is not only to ensure that teachers teach with nutrition and high quality in accordance with the 21 st century, but also allocates 4 other national standards (National Council of Teachers of Mathematics, 2000) to support teacher professional assignments (Manullang \& Rajagukguk, 2016): educators and education personnel, financing, infrastructure and governance.

\section{Conclussion}

Student achievement in the form of UN scores and their acceptance at well-known universities at home and abroad over the past 10 years shows indications of institutional capacity in terms of their readiness to be a good learning environment and to foster learning initiatives. Accreditation A and B shows that MAN IC is internally in accordance with the quality of the SNP, and is recognized externally by BAN S/M. PMP instrument consisting of 8 standards and broken down into 132 items. Madrasas that have regularly evaluated themselves are then proven by good and superior accreditation status, indicating that the process and results of madrasas are in accordance with the vision, mission and objectives.

The principle of madrasa has made a good madrasa environment into a learning organization with leadership abilities, optimization and efficiency of human resources, learning resources and social potential. The principle of madrasa who is strictly selected has personality, managerial, entrepreneurship, supervision and social competencies, of course, to be performance capital (process and realization of competencies). Likewise their high academic degrees and degrees. Their managerial abilities strengthen accountability and transparency in governance and the effectiveness of resources, while regular and ongoing academic supervision encourages ease of collaboration between teachers and teachers with education personnel preventing imbalances in the quality of the process and learning outcomes. Academic levels and teacher certification make teachers have good welfare, so pedagogical, personal, social, and professional competencies support their performance as part of the process and realization of competencies. Teacher creativity increases, the atmosphere of the classroom with the learning process [approaches, methods, etc.,] and planned and supervised evaluation. Madrasa supervisors and ministry of religious affairs in district/city level up to the madrasa directorate at the central office have good monitoring and evaluation. Supervisors who have personal competence, academic supervision, educational evaluation, research and development, social, and managerial supervision, become performance instruments of supervisor competency realization in order to improve the quality of madrasas. 


\section{Acknowledgment}

Thank you to Dr. Ahmad Umar and Dr. Ahmad Hidayatullah are the directors of the KSKK madrasa and the Deputy of Curriculum and Learning KSKK Madrasa has helped the data, alsoAde Auora Imani, S. Ked., and Ikmal B. Wafira has helped read the data.

\section{References}

[1] Aaronson, Daniel; Barrow, Lisa; and Sander, William, "Teachers and Student Achievement in the Chicago Public High Schools", Journal of Labor Economics Vol. 25, No. 1, January 2007

[2] Adeyemi, T. O., "Principals' leadership styles and teachers' job performance in senior secondary schools in Ondo State, Nigeria", Journal of Education Administration and Policy Studies, Vol. 2 (6), July 2010

[3] Afshar, Hassan Soodmand dan Doosti, Mehdi, "Investigating the impact of job satisfaction/dissatisfaction on Iranian English teachers' job performance", Iranian Journal of Language Teaching Research, 4 (1), Jan., 2016

[4] Anders, Yvonne, et. al., Early Science Education - Goals and Process-Related Quality Criteria for Science Teaching. Berlin: Verlag Barbara Budrich, 2018

[5] Arman, Thalib, Syamsul Bachri and Manda, Darman Manda, "The effect of school supervisors competence and school principals competence on work motivation and performance of Junior High School teachers in Maros Regency, Indonesia",International Journal of Environmental and Science Education, Vol. 11, No.15, 2016

[6] Bahzar, Moh, "Authentic Leadership in Madrassas: Asserting Islamic Values in Teacher Performance", Journal of Social Studies Education Research, 10 (1), 2019

[7] Bello, Garba Bala Bello and Jakada, Muhammad Bello, "Monetary Reward and Teachers' Performance in Selected Public Secondary Schools in Kano", Journal of Education and Practice, Vol. 8, No.7, 2017

[8] Blömeke, Sigrid;Hoth, Jessica;Döhrmann, Martina;Busse, Andreas; Kaiser, Gabriele danKönig, Johannes, "Teacher Change During Induction: Developmentof Beginning Primary Teachers' Knowledge, Beliefs and Performance”, International Journal of Science and Math Education, 13, 2015

[9] Campbell, Patricia F. and Malkus, Nathaniel N., "The Impact of Elementary Mathematics Coaches on Student Achievement", The Elementary School Journal, Vol. 111, No. 3, March 2011

[10] Cardwell, Michelle E., "Patterns of Relationships Between Teacher Engagement and Student Engagement", thesis submitted in partial fulfillment of the requirements for the degree Ed.D. in Executive Leadership, Ralph C. Wilson, Jr. School of Education St. John Fisher College, August 2011

[11] Chen, Junjun, "Efficacious and Positive Teachers Achieve More: Examining the Relationship Between Teacher Efficacy, Emotions, and Their Practicum Performance", Asia-Pacific Educational Research, Springer, 2018

[12] Condon, Christopher; Clifford, Matthew, "Measuring Principal Performance: How Rigorous Are Commonly Used Principal Performance Assessment Instruments? A Quality School Leadership Issue Brief. Revised",American Institutes for Research, 2012

[13] Corcoran, Roisin P. \& Tormey, "Roland Does emotional intelligence predict student teachers' performance?"Teaching and Teacher Education, 35, 2013

[14] Creswell, John W., Educational Research: Planning, Conducting and Evaluating Quantitative and Qualitative Research. Boston: Pearson, 2012

[15] Dewi, Erni R.; Bundu, Patta and Tahmir, Suradi, "The influence of the antecedent variable on the teachers' performance through achievement motivation in senior high school", International Journal Of Environmental \& Science Education, Vol. 11, No. 9, 2016 
[16] Duckworth, Angela Lee; Quinn, Patrick D. and Seligman, Martin E. P., "Positive predictors of teacher effectiveness", The Journal of Positive Psychology, Vol. 4, No. 6, November 2009

[17] Dunekacke, Simone; Jenßen, Lars \& Sigrid Blömeke, "Effects of Mathematics Content Knowledge on Pre-school Teachers' Performance: a Video-Based Assessment of Perception and Planning Abilities in Informal Learning Situations", International Journal of Science and Mathematical Education, Springer, 2015

[18] Economist Intelligence Unit,The learning curve: lessons in country performance in education,2012. Retrieved from: http://thelearningcurve.pearson.com/

[19] Effendy, Bahtiar, Prasetyo, Hendro dan Subhan, Arief, "Munawir Syadzali, MA: Pencairan Keterangan Ideologis", Azyumardi Azra dan Saiful Umam (ed), Menteri-Menteri Agama RI: Biografi Sosial Politik. Jakarta: INIS, 1998

[20] Friedrich, J., The Human Resource and Performance in Application of Teacher Profession. Boston: Harvard Business School Press, 2013

[21] Glasser, William, Control Theory in the Classroom. New York: Harper \& Row, 1986

[22] Glasser, William, "The Quality School”,The Phi Delta Kappan, Vol. 71, No. 6, Feb., 1990

[23] Goldhaber, Dan, (2002), The Mystery of God Teaching, Education Next,Spring 2002

[24] Goldhaber, Dan dan Brewer, Dominc J., "Does Teacher Certification Matter? High School Teacher Certification Status and Student Achievement", Education Evaluation and Policy Analysis, Vol. 2, No. 2, Summer 2000

[25] Ha, Bong-Woon dan Sung, Youl-Kwan, "Teacher reactions to the performance-based bonus program: how the expectancy theory works in the South Korean school culture", Asia Pacific Educational Review, 12, 2011

[26] Hanushek, Eric A., "The Impact of Differential Expenditures on School Performance", Educational Researcher, Volume: 18 issue: 4, May 1989

[27] Hayadin, "Orientasi Pilihan Studi Dan Profesi Siswa Madrasah Aliyah Negeri Insan Cendekia (MAN-IC) Serpong, Banten”, EDUKASI: Jurnal Penelitian Pendidikan Agama dan Keagamaan, 17(1), 2019

[28] Hoadley, Ursula dan Galant, Jaamia, "Specialization and School Organization: Investigating Pedagogic Culture",British Journal of Sociology of Education, 37/8, 2016

[29] Jacob, Brian A., et. al., "Teacher applicant hiring and teacher performance: Evidence from DC public schools", Journal of Public Economics, 166, 2018

[30] Johari, Johanim; Tan, Fee Yean; Tjick, Zati Iwani; Zulkarnain, "Autonomy, workload, work life balance and job performance teachers", International Journal of Educational Management, Vol. 32 No. 1,2018

[30] Johari, Johanim \& Yahya, Khulida Kirana, "Job Characteristics, Work Involvement and Job Performance of Public Servants", European Journal of Training and Development, Vol. 40 Iss 7, 2016

[31] Kain, John F., "The Impact of Individual Teachers and Peers on Individual Student Achievement", paper presented at The 20th Annual Research Conference, the Association for Public Policy Analysis and Management (APPAM), Grand Hyatt, New York, October 31, 1998

[32] Karatas, Suleyman, "The School Principle's Opinions on Working as Enquirers: A Case Study", European Journal of Education Studies, Vol. 9 Issue 5, 2019

[33] Kendra, McKenzie, "The Effects of Poverty on Academic Achievement",BU Journal of Graduate Studies in Education, Vol. 11 No. 2, 2019

[34] Klassena, Robert M., Yerdelenc, Sündüs, Durksen, Tracy L., "Measuring Teacher Engagement: Development of the Engaged Teachers Scale (ETS)", Frontline Learning Research 2, 2013

[35] Kukia-Acevedo, Sharon, "Do teacher characteristics matter? New results on the effects of teacher preparation on student achievement", Economic of Education Review, Vol. 28 Issue 1, 2009

[36] Maftuhin, Arief, Santri Kaliwates: Dari MAPK Untuk Indonesia. Ciputat: Penerbit Haja, 2020

[37] Manullang, Martua \& Rajagukguk, Waminton, "Some Factors that Affecting the Performance of Mathematics Teachers in Junior High School in Medan", International Education Studies, Vol. 9, No. 4, 2016

[38] McNeil, Linda M., "Contradiction of Control”, The Phi Delta Kappan, Vol. 71, No. 6, March 1988 
[39] Ordu, Aydan, "The effects of diversity management on job satisfaction and individual performance of teachers", Educational Research and Reviews, Vol. 11 (3), February, 2016

[40] Papilaya, Josef; Tuakora, Paulus dan Rijal, Muhammad, "Compensation, Transparency, and Motivation Effects on the Performance of Junior High School Teachers in Western Seram, Indonesia”, International Journal of Instruction, Vol.12, No.3, July 2019

[41] Pianta, R. C., Hamre, B. K., \& Allen, J. P. "Teacher-student relationships and engagement: Conceptualizing, measuring, and improving the capacity of classroom interactions",in S. L. Christenson, A. L. Reschly, \& C. Wylie (Eds.), Handbook of research on student engagement. Dordrecht, Netherlands: Springer, 2012

[42] Pranoto, Iwan, Kasmaran Berilmu Pengetahuan. Jakarta: KPG, 2019

[43] Pusporini, Widowati, Triatna, Cepi, Syahid, Achmad dan Kustandi, Cecep, "Is the Education Quality in Indonesia Equal? An Analysis on the Findings of Principal Partnership Program", European Journal of Educational Research, Volume 9, Issue 3, July, 2020

[44] Rahim, M. Husni, Arah baru Pendidikan Islam di Indonesia. Jakarta: Logos, 2001

[45] Rahmatullah, Mamat, "The Relationship between Learning Effectiveness, Teacher Competence and Teachers Performance Madrasah Tsanawiyah at Serang, Banten, Indonesia", Higher Education Studies, Vol. 6, No. 1, 2016

[45] Rezaee, Afshin, et. al., “A Mixed Method Study of the Relationship between EFL Teachers' Job Satisfaction and Job Performance in Iran", International Journal of Instruction, Vol.11, No.4, October 2018

[46] Rimm-Kaufman, S. E., \& Hamre, B. K. "The role of psychological and developmental science in efforts to improve teacher quality",Teachers College Record, 112, 2010

[47] Rockoff, Jonah E., "The Impact of Individual Teachers on Student Achievement: Evidence from Panel Data", American Economic Review, Vol. 94, No. 2, 2004

[48] Ross, John A. \& Gray, Peter, "Transformational leadership and teacher commitment to organizational values: The mediating effects of collective teacher efficacy”,School Effectiveness and School Improvement, 17(2), 2006

[49] Saifuddin, Lukman Hakim, "Moderasi Beragama", Lince Sihombing, et.al., Gagasan - Kinerja Lukman Hakim Saifuddin: Moderasi Beragama dan Transformasi Kelembagaan Pendidikan. Jakarta: Rohobot Literature, 2019

[50] Santin, Daniel dan Sicilia, Gabriela, "Using DEA for measuring teachers' performance and the impact on students' outcomes: evidence for Spain”, Journal of Productivity Analysis, Springer, 49(1) 2018

[51] Schaufeli, W.B., Salanova, M., Gonza'lez-Roma', V., \& Bakker, A. B.,"The measurement of burnout and engagement: A confirmative analytic approach",Journal of Happiness Studies, 3, 2002

[52] Secker, Clare E. Von dan Lissitz, Robert W., "Estimating the Impact of Instructional Practices on Student Achievement in Science", Journal of Research in Science Teaching, Vol. 36, Issue 10, Dec 1999

[53] Sirait, Swando,"Does Teacher Quality Affect Student Achievement? An Empirical Study in Indonesia", Journal of Education and Practice, Vol.7, No.27, 2016

[54] Skaggs, Gary dan Bodenhorn, Nancy, "Relationships Between Implementing Character Education, Student Behavior, and Student Achievement", Journal of Advance Academics, 18, November 2006

[55] Spinath, Birgit, Academic Achievement, in V. S. Ramachandran (ed), Encyclopedia of Human Behavior, 2nd ed, Vol. 1, San Diego: Academic Press, March 2012

[56] Staiger, D. O., \& Rockoff, J. E.,"Searching for effective teachers with imperfect information",Journal of Economic Perspectives, 24, 2010

[57] Steenbrink, Karel, Pesantren, Madrasah dan Sekolah: Pendidikan dalam Kurun Modern. Jakarta: LP3ES, 1986

[58] Sumantri, Mohamad Syarif\& Whardani, Prayuningtyas Angger," Relationship between Motivation to Achieve and Professional Competence in the Performance of Elementary School Teachers", International Education Studies, Vol. 10, No. 7, 2017 
[59] Syahid, Achmad,"Madrasah in Indonesia: The Melting Pot Between Religious Obligations and State Mission",paper presented in International Conference - Workshop on Madrasah, Education and Culture Attaché, Embassy of the Republic of the Indonesia in colaboration with Center for Islamic Studies, The University of the Philippines, Diliman Campus, Manila, 4-5th July, 2018

[60] Taylor, Leah \& Parsons, Jim, "Improving Student Engagement", Current Issues in Education, Vol. 14 No. 1,2011

[61] Tribus, Myron, Selected Papers on Quality and Productivity Improvement. Washington: Engineers, 1984

[62] Wahyuddin, Wawan, "The Relationship between of Teacher Competence, Emotional Intelligence and Teacher Performance Madrasah Tsanawiyah at District of Serang Banten", Higher Education Studies, Vol. 6, No. 1, 2016

[63] Warren, Jeffrey M.;Hale, Robyn W., "The Influence of Efficacy Beliefs on Teacher Performance and Student Success: Implications for Student Support Services", Journal of Ratio-Emotion Cognitive-Behavior Therapy, 2016

[64] Witte, Kristof De; Titl, Vitezslav; Holz, Oliver and Smet, Mike, Financing Quality Education for All: The Funding Methods of Compulsory and Special Needs Education.Leuven: Leuven University Press, 2019

[65] Department of Education and Training, Australian Government, Quality Schools, Quality Outcomes, May, 2016

[66] National Council of Teacher of Mathematics. Principles and Standards for School Mathematics. Reston, VA: NCTM, 2000.

[67] National Association of Charter School Authorizers, Principles and Standards for Quality Charter School Authorizing, Chicago, 2018 Edition

[68] Official website of MAN IC in Indonesia

[69] Official webiste of BAN S/M 